J. Pijar MIPA, Vol. VI No.2, September : 65 - 69

ISSN 1907-1744

\title{
PEMBELAJARAN REMEDIAL KONSENTRIS UNTUK MENGAKSELERASI HASIL BELAJAR SISWA LAMBAT MENCAPAI KOMPETENSI PADA PEMBELAJARAN KIMIA DI SMA NEGERI 1 NARMADA
}

\author{
Sumardiyanto ${ }^{1)}$, Yayuk Andayani ${ }^{2)}$, Muntari ${ }^{2)}$ \\ ${ }^{1)}$ Pengawas SMA Mapel Kimia Dinas Dikbud Lombok Barat \\ ${ }^{2}$ FKIP Universitas Mataram
}

\begin{abstract}
Abstrak : Siswa dalam suatu kelas umumnya dapat dikategorikan menjadi tiga kelompok, yaitu siswa lambat belajar, siswa normal/rata-rata, dan siswa cepat belajar. Jika keadaan demikian dibiarkan berlarut, maka pada gilirannya nanti siswa lambat belajar akan mengalami kegagalan belajar yaitu tidak naik kelas atau tidak lulus ujian pada akhir semester. Solusinya adalah menciptakan sistem pembelajaran yang mampu mengakomodasi semua siswa sehingga pada akhir waktu pembelajaran yang ditetapkan seluruh siswa dapat dinyatakan tuntas belajar. Model pembelajaran yang diteliti adalah penerapan pembelajaran remedial konsentris. Penelitian ini bertujuan untuk menjajaki: bagaimana keefektifan penerapan model pembelajaran remedial konsentris dan pembelajaran konvensional untuk mengakselerasi hasil belajar siswa lambat mencapai kompetensi pada pembelajaran kimia. Metode penelitian yang diterapkan adalah penelitian eksperimen kuasi menggunakan bentuk "Desain kelompok kontrol/pembanding pretes-postes tidak setara". Data hasil belajar kognitif dikumpulkan melalui teknik tes tertulis bentuk objektif. Penelitian dilaksanakan di SMA Negeri 1 Narmada pada tahun pembelajaran 2009/2010, dengan jumlah sampel sebanyak 76 siswa yang terbagi atas 2 kelas paralel. Data dianalisis pada taraf signifikan 0,05 (5\%) menggunakan program Statistical Product and Service Solutions for Windows version 16.0 (SPSS 16.0). Hasil penelitian menunjukkan: (1) Ada perbedaan akselerasi hasil belajar siswa lambat mencapai kompetensi pada pembelajaran kimia yang diperlakukan menggunakan model pembelajaran remedial konsentris dan pembelajaran konvensional $(\mathrm{p}<0,05)$. (2) Penerapan model pembelajaran remedial konsentris lebih efektif dibandingkan dengan pembelajaran konvensional untuk mengakselerasi hasil belajar siswa lambat mencapai kompetensi pada pembelajaran Kimia $(\mathrm{p}<0,05)$.
\end{abstract}

Kata kunci : Pembelajaran Remedial Konsentris, Akselerasi Hasil Belajar.

Abstract : Students in a class can generally be categorized into three groups, namely students slow learning, students normal / average, and students quickly learn. If circumstances allowed to go on, then in turn slow learners will fail to learn that are they will not being promoted to the upper grade or do not pass the exam at the end of the semester. The solution is to create a learning system that is able to accommodate all students so that at the end of a specified time learning all students to pass the study. Learning model that investigated the application of concentric remedial learning. This study aims to explore: how the effectiveness of the implementation of remedial learning model of concentric and conventional learning to accelerate slow learning students outcomes to achieving competence in learning chemistry. The research method applied is a quasi experimental study using a form of "Nonequivalent pretest-posttest control/ comparison group design". Cognitive learning outcomes data were collected through a written test of objective form. The experiment was conducted at SMA Negeri 1 Narmada in the academic year 2009/2010, with a sample of as many as 76 students were divided into two parallel classes. Data were analyzed on a significant level of $0.05(5 \%)$ using the program Statistical Product and Service Solutions for Windows version 16.0 (SPSS 16.0). The results showed that implementation of remedial concentric model of learning is more effective than conventional learning to accelerate student learning outcomes later achieve competence in teaching Chemistry $(\mathrm{p}<0.05)$.

Keyword : Concentric Remedial Learning, Accelerate Learning Outcomes.

\section{PENDAHULUAN}

Salah satu masalah besar dalam bidang pendidikan adalah rendahnya mutu pendidikan yang tercermin dari rendahnya rata-rata prestasi belajar, khususnya siswa SMA. Proses pembelajaran masih didominasi peran guru (teacher centered), serta kurang memperhatikan ketuntasan belajar secara individual, belum menerapkan pembelajaran sampai peserta didik menguasai kompetensi materi pembelajaran secara tuntas, akibatnya banyak peserta didik yang tidak menguasai materi pembelajaran meskipun sudah dinyatakan tamat dari sekolah [1]. Realita di lapangan mengindikasikan bahwa dalam proses pembelajaran di kelas selalu ada siswa yang mengalami lambat belajar, sehingga siswa tersebut tidak mampu mencapai target kriteria ketuntasan belajar minimal (KKM) yang telah ditetapkan. Akibat yang terjadi bagi siswa yang bersangkutan: (1) Tidak lulus ujian nasional bagi siswa kelas XII atau tidak naik kelas bagi siswa kelas X atau XI di jenjang pendidikan tingkat SMA. (2) Pada umumnya pujian selalu muncul terhadap siswa yang cepat belajar, sementara perhatian terhadap siswa yang mengalami lambat belajar masih kurang.

Proses pembelajaran konvensional pada umumnya dilaksanakan dengan pembelajaran dalam konteks klasikal, sifatnya berpusat pada guru/pendidik, proses pembelajaran bersifat linear serta penyajian materi pelajaran terus berkelanjutan, dengan sasaran utama target kurikulum tanpa memperhatikan ketuntasan belajar peserta didik secara individual [1]. Pembelajaran konvensional tidak mempunyai sintaks yang jelas, sehingga tidak mempunyai bentuk model pembelajaran. Pada umumnya pembelajaran diawali dengan apersepsi (tanya jawab 
J. Pijar MIPA, Vol. VI No.2, September : 65 - 69

klasikal seputar materi yang akan dipelajari). Selanjutnya pada kegiatan inti, guru melaksanakan proses pembelajaran secara konvensional menggunakan metode ceramah bermakna atau tanya jawab secara klasikal. Kegiatan penutup dengan merangkum materi pelajaran yang baru saja dipelajari dan diakhiri dengan postes. Nilai akhir peserta didik diperoleh didasarkan pada rata-rata tes formatif, sehingga tidak mencerminkan hasil penguasaan terhadap kompetensi dasar/KD tertentu.

Setiap analisis hasil ulangan (postes) selalu memunculkan kurva normal, hal ini dapat digunakan sebagai pemetaan terhadap siswa lambat, siswa normal/ rata-rata, dan siswa cepat belajar. Permasalahan yang timbul adalah bagaimana mengelola siswa yang lambat belajar, sehingga pada akhir alokasi waktu pembelajaran yang ditetapkan seluruh siswa dapat dinyatakan tuntas belajar.

Ketuntasan belajar dalam KTSP ditetapkan dengan penilaian acuan patokan (criterion referenced) pada setiap kompetensi dasar (KD) dan tidak ditetapkan berdasarkan norma (norm referenced). Batas ketuntasan belajar (kriteria ketuntasan minimal/KKM) harus ditetapkan oleh guru, misalnya peserta didik harus mencapai nilai 65 atau sampai nilai berapa seorang peserta didik dinyatakan mencapai ketuntasan dalam belajar [1]. Nilai batas minimal KKM yang ditetapkan oleh guru tidak boleh lebih rendah dari KKM yang ditetapkan oleh pemerintah (KKM rata-rata pada ujian nasional 2010 adalah 5,50) [2]. Penelitian ini, dengan materi pokok senyawa Hidrokarbon (menggunakan nilai KKM=65).

Pendekatan pembelajaran tuntas adalah salah satu usaha dalam pendidikan yang bertujuan untuk memotivasi peserta didik mencapai penguasaan (mastery level) terhadap kompetensi tertentu [1]. Implikasinya terhadap sistem pembelajaran di sekolah bahwa setiap pendidik/ guru akan selalu berupaya tentang bagaimana cara menyajikan sistem pembelajaran terbaik. Menentukan solusi tentang pemecahan masalah pembelajaran, guru yang kreatif akan selalu mencari model pembelajaran yang baru, menciptakan suasana belajar yang lebih aktif, kreatif, demokratis, kolaboratif, dan kontruktif [3]. Mengantisipasi hal tersebut, maka solusinya adalah menciptakan sistem pembelajaran yang mampu mengakomodasi semua siswa, sehingga pada akhir alokasi waktu pembelajaran yang ditetapkan seluruh siswa dapat dinyatakan tuntas belajar.

Pembelajaran remedial konsentris adalah strategi pembelajaran yang didesain sedemikian rupa dimana materi pembelajaran berikut proses pembelajarannya disajikan secara berulang (menggunakan strategi penyampaian materi secara simultan), dengan penekanan terhadap materi yang belum dikuasai oleh siswa yang mengalami lambat belajar (berpusat pada siswa/stundent centered) sehingga terjadi penguatan ingatan (retensi), dan membuat hasil belajar siswa menjadi lebih baik/lebih tinggi dari sebelumnya $[4,5]$.

Sintaks pembelajaran remedial konsentris, mengacu pada Dick dan Caray [4]: (1) Meneliti kasus dengan permasalahannya sebagai titik tolak layanan pembelajaran berikutnya. Berdasarkan analisis hasil pretes/postes, peserta didik yang belum mencapai KKM sebagai subjek target pembelajaran remedial. (2) Menentukan tindakan yang harus dilakukan (mempersiapkan pelaksanaan proses pembelajaran remedial). (3) Pemberian layanan khusus yaitu bimbingan dan konseling. Jika diperlukan, pemberian layanan khusus dapat meminta bantuan dari guru BK dan atau dapat dilakukan oleh guru sendiri dengan tujuan mengusahakan agar peserta didik terbebas dari hambatan mental emosional sehingga siap menghadapi kegiatan belajar secara wajar. (4) Langkah pelaksanaan pembelajaran remedial konsentris. Pelaksanaan pembelajaran remedial konsentris merupakan kegiatan pembelajaran klasikal yang difokuskan terhadap peserta remedial, mengulang kembali materi dan proses pembelajarannya dengan penekanan pada materi yang belum dikuasai. (5) Melakukan pengukuran kembali terhadap prestasi belajar siswa. Hal ini dilakukan melalui postes kedua, yang kualitasnya sama dengan postes pertama. (6) Melakukan re-evaluasi dan re-diagnostik. Hasil pengukuran yang dilakukan pada langkah ke lima kemudian dianalisis, bagi peserta didik yang belum mencapai kompetensi (KKM) diberikan pembelajaran remedial ulang dengan lebih intensif pada penekanan materi yang belum dikuasai, sementara bagi peserta didik yang sudah mencapai kompetensi (KKM) diberikan pembelajaran pengayaan.

Penelitian ini bertujuan untuk menjajaki: Bagaimana keefektifan penerapan model pembelajaran remedial konsentris dan pembelajaran konvensional untuk mengakselerasi hasil belajar siswa lambat mencapai kompetensi pada pembelajaran kimia.

\section{METODE PENELITIAN}

Penelitian ini dilaksanakan di SMAN 1 Narmada pada semester genap tahun pelajaran 2009/2010. Metode penelitian terdiri dari dua tahap, yakni penelitian pengembangan dan penelitian eksperimen. Penelitian pengembangan digunakan untuk menghasilkan produk tertentu dan menguji keefektifan produk tersebut [6], mengembangkan produk baru berupa model pembelajaran di kelas berdasarkan produk yang telah ada [7]. Pengembangan rancangan model pembelajaran yang diimplementasikan melalui perangkat pembelajaran (RPP, LKS, dan instrumen penilaian) yang mengacu pada model perencanaan dan pengembangan pengajaran menurut Dick \& Carey. Penelitian eksperimen kuasi digunakan untuk menguji keefektifan produk pembelajaran tersebut dalam implementasinya di kelas eksperimen dengan membandingkan terhadap pembelajaran konvensional.

Pengembangan perangkat pembelajaran yang dijabarkan kedalam RPP, LKS, dan instrumen penilaian, dengan materi pokok "Senyawa Hidrokarbon" pada kompetensi dasar (KD) "Mendeskripsikan kekhasan atom karbon dalam membentuk senyawa hidrokarbon" dan "Menggolongkan senyawa hidrokarbon berdasarkan strukturnya dan hubungannya dengan sifat senyawa".

Penelitian eksperimen kuasi yang digunakan adalah "desain kelompok kontrol/pembanding pretespostes tidak setara (nonequivalent pretest-posttest control/ comparison group design)" [6, 8]. Eksperimen dilakukan terhadap dua kelompok sampel, dengan mengupayakan (memilih) kedua kelompok sampel setara. Terhadap kedua kelompok sampel diberikan tes awal (pretes), kemudian 
kelompok eksperimen diberikan perlakuan menggunakan model pembelajaran remedial konsentris, dan kelompok kelompok kontrol tidak diberikan perlakuan khusus tetapi menggunakan pembelajaran konvensional. Untuk mengukur keefektifan model pembelajaran (perlakuan), terhadap masing-masing kelompok sampel diberikan tes akhir (postes).

Postes dilaksanan pada setiap akhir pertemuan pembelajaran (pembelajaran dilaksanakan untuk tiga kali pertemuan dan dilakukan tiga kali postes). Nilai hasil pretes, postes I, postes II, dan postes III (postes akhir) digunakan untuk analisis kecepatan pemahaman siswa mencapai KKM terhadap model pembelajaran. Namun demikian hasil postes III (postes akhir) merupakan representasi terhadap akselerasi hasil belajar mencapai kompetensi, yang merupakan akumulasi terhadap percepatan hasil belajar setelah materi pembelajaran disampaikan secara keseluruhan, sehingga untuk keefektifan model pembelajaran digunakan analisis data dari nilai hasil postes III.

Populasi penelitian adalah seluruh siswa kelas X semester genap di SMA Negeri 1 Narmada tahun pembelajaran 2009/2010 sebanyak 372 siswa yang tersebar dalam 9 (sembilan) kelas (rombongan belajar). Penarikan sampel menggunakan sampel klaster purposif yaitu anggota sampel dipilih secara sengaja pada kelompok-kelompok kelas dari populasi yang dianggap homogen berdasarkan nilai Kimia pada raport semester 1 dan nilai hasil ulangan semester 2 pada kompetensi dasar (KD) sebelumnya, kemudian diambil 2 (dua) kelas sebagai sampel. Oleh karena itu sampel penelitian ini merupakan sampel nonprobabilitas dimana anggota populasi tidak diberi kesempatan (peluang) yang sama untuk dipilih menjadi anggota sampel [8].

Teknik analisis data hasil penelitian menggunakan uji " $t$ " pada taraf signifikan $0,05(5 \%)$ menggunakan program SPSS 16.0.

\section{HASIL PENELITIAN DAN PEMBAHASAN A. Kemajuan Hasil Belajar Siswa Mencapai KKM}

Penelitian ini diperlakukan terhadap subjek penelitian sebanyak 32 siswa yang sekaligus mengikuti pretes, postes I, postes II, dan postes III, oleh siswa yang sama untuk masing-masing kelompok sampel. Analisis efektifitas model pembelajaran terhadap akselerasi hasil belajar ranah kognitif mencapai KKM diberlakukan terhadap persentase perolehan nilai hasil pretes, postes I, postes II, dan postes III (postes akhir) bagi siswa yang memperoleh nilai mencapai KKM.

Perolehan persentase nilai hasil pretes terhadap masing-masing kelompok sampel tidak ada yang mencapai KKM (0\%), sementara persentase nilai mencapai KKM pada postes I, postes II, dan postes III umumnya meningkat. Namun demikian hasil postes III (postes akhir) merupakan representasi terhadap akselerasi hasil belajar mencapai kompetensi, yang merupakan akumulasi terhadap percepatan hasil belajar, kecepatan pemahaman siswa, serta daya serap terhadap pembelajaran, setelah materi pembelajaran tuntas disampaikan pada masingmasing kelompok sampel secara keseluruhan. Persentase jumlah siswa yang memperoleh nilai mencapai KKM pada masing-masing kelompok sampel, disajikan seperti Grafik berikut:

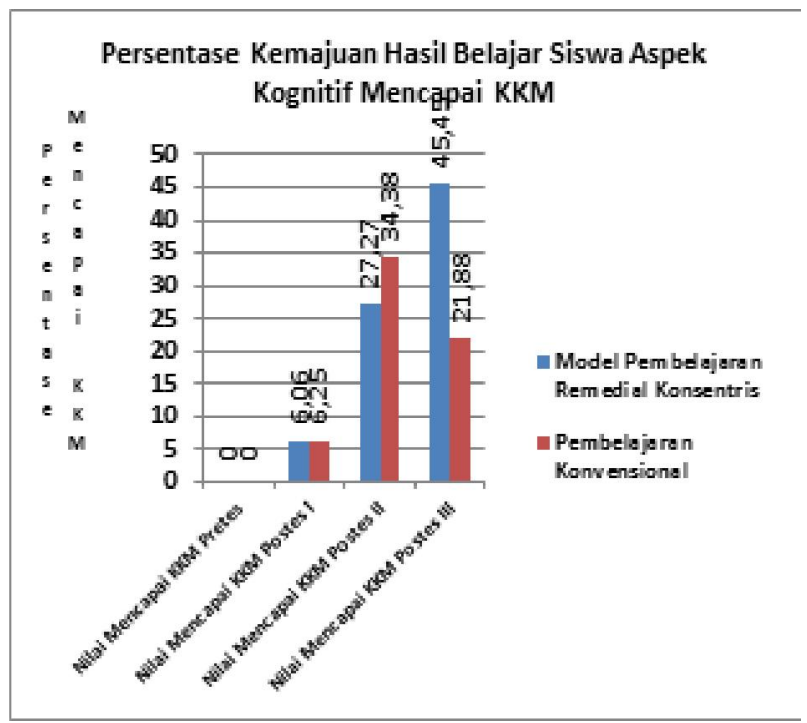

Gambar 1. Grafik Persentase Kemajuan Hasil Belajar Siswa (Aspek Kognitif) Mencapai KKM

Berdasarkan persentase perolehan nilai mencapai KKM pada hasil postes III (postes akhir), keefektifan model pembelajaran terhadap akselerasi hasil belajar ranah kognitif yang diperlakukan menggunakan model pembelajaran remedial konsentris $(45,45 \%)$ lebih efektif dari pembelajaran konvensional $(21,88 \%)$. Hal ini menunjukkan bahwa model pembelajaran yang diperlakukan pada kelas eksperimen memberikan peluang hasil belajar mencapai KKM yang lebih tinggi dibandingkan pembelajaran konvensional.

\section{B. Uji Hipotesis terhadap Rata-Rata Nilai Hasil Pretes dan Postes Akhir}

Data hasil penelitian terhadap rata-rata nilai hasil pretes dan postes akhir disajikan dalam tabel berikut:

Tabel 1. Rata-Rata Nilai Hasil Pretes dan PostesAkhir

\begin{tabular}{|c|l|c|c|}
\hline No & Model Pembelajaran & Pretes & Postes \\
\hline 1 & $\begin{array}{l}\text { Pembelajaran Remedial } \\
\text { Konsentris }\end{array}$ & 19,44 & 62,91 \\
\hline 2 & $\begin{array}{l}\text { Pembelajaran } \\
\text { Konvensional }\end{array}$ & 21,88 & 54,72 \\
\hline
\end{tabular}

a. Uji Kesamaan Rata-Rata Nilai Hasil Belajar Sebelum Perlakuan (Pretes) terhadap Model Pembelajaran yang Berbeda

Hasil analisis menggunakan uji " $t$ " menunjukkan nilai rata-rata hasil pretes pada Pembelajaran Remedial Konsentris 19,44 dan Pembelajaran Konvensional 21, 88. Besarnya korelasi antara kedua sampel 0,199 dengan angka signifikansi $0,275(\mathrm{p}>0,05)$, dan angka signifikansi perbedaan rata-rata hasil pretes $0,163(\mathrm{p}>0,05)$. Hal ini berarti tidak ada perbedaan rata-rata nilai hasil pretes (kemampuan awal siswa terhadap materi pembelajaran pada masing-masing kelas sampel sebelum perlakuan 
J. Pijar MIPA, Vol. VI No.2, September : 65 - 69

adalah sama), sehingga hasil belajar yang dicapai siswa pada akhir pembelajaran hanya dipengaruhi oleh faktor perlakuan model pembelajaran.

\section{b. Uji Perbedaan Rata-Rata Nilai Hasil Belajar Sesudah Perlakuan (Postes) terhadap Model Pembelajaran yang Berbeda}

Digunakannya data postes III (postes akhir) dalam uji perbedaan rata-rata nilai hasil belajar sesudah perlakuan terhadap model pembelajaran yang berbeda, dengan asumsi bahwa pada pelaksanaan postes III (postes akhir) materi pembelajaran sudah disampaikan secara keseluruhan, sehingga hasil postes akhir mencerminkan hasil belajar siswa akibat perlakuan model pembelajaran yang berbeda.

Hasil uji perbedaan rata-rata nilai hasil belajar sesudah perlakuan (postes) menunjukkan nilai rata-rata hasil postes pada Pembelajaran Remedial Konsentris 62,91 dan Pembelajaran Konvensional 54,72. Besarnya korelasi antara kedua sampel 0,03 dengan angka signifikansi 0,872 ( $\mathrm{p}>0,05)$, dan angka signifikansi perbedaan rata-rata hasil postes $0,027(\mathrm{p}<0,05)$. Hal ini berarti: (1) Tidak ada hubungan yang signifikan antara Pembelajaran Remedial Konsentris dan Pembelajaran Konvensional. (2) Ada perbedaan rata-rata nilai hasil postes dengan menggunakan model pembelajaran yang berbeda.

Keefektifan model pembelajaran yang diperlakukan terhadap kelas eksperimen didukung hasil penelitian Chrisnajanti [5], bahwa hasil rata-rata belajar siswa sesudah remedial lebih tinggi dari pada rata-rata hasil belajar sebelum remedial. Menurut Caray [4], sesuai dengan bentuk pembelajaran remedial yang bersifat menyembuhkan atau membetulkan terhadap hambatan kepribadian yang berkaitan dengan kesulitan belajar, sehingga pembelajaran menjadi lebih baik dari sebelumnya.

Strategi pembelajaran remedial konsentris, bahwa melalui pengulangan materi akan memperkuat daya ingat siswa terhadap materi pembelajaran sehingga usaha mengkonstruksi pengalaman (hasil belajar) akan lebih mudah dilakukan. Pelaksanaan pembelajaran remedial konsentris, perhatian guru lebih difokuskan terhadap pemberian layanan khusus bagi siswa yang mengalami lambat belajar, menempatkan fungsi guru sebagai fasilitator sehingga memberikan pengawasan yang tidak otoriter [9]. Hal ini akan menyumbangkan andil besar dalam membangun aktivitas siswa sehingga berpeluang terhadap upaya siswa mengkonstruksi pengalaman hasil belajar, menggali potensinya sendiri sehingga daya serap siswa terhadap pembelajaran akan semakin baik, yang pada gilirannya hasil belajar siswa mencapai kompetensi semakin tinggi.

Pada pembelajaran konvensional, strategi pembelajarannya lebih bersifat klasikal dan kurang memperhatikan ketuntasan belajar individual, hal ini menyebabkan kontrol terhadap pembelajaran agak terabaikan, sehingga sangat memungkinkan hasil belajar tersebut menjadi rendah. Berdasarkan perbedaan nilai ratarata, model pembelajaran remedial konsentris (rata-rata= $62,06)$ lebih efektif dibandingkan dengan pembelajaran konvensional (rata-rata $=54,72$ ). Beberapa alasan yang mendukung, yakni: (1) Pembelajaran remedial konsentris adalah suatu model pembelajaran yang berpusat pada siswa, dimana materi pembelajaran berikut proses pembelajarannya disajikan secara berulang (menggunakan strategi urutan penyampaian materi secara simultan), sehingga peserta didik dapat menguasai kompetensikompetensi yang harus dicapai dalam pembelajaran dengan jalan berperan aktif. Melalui strategi pembelajaran yang diulang secara simultan dengan penekanan terhadap materi yang belum dikuasai oleh siswa lambat, akan memberikan dampak pengiring yakni dapat memperkuat dan mempertajam daya ingat (retensi) siswa terhadap materi pelajaran, sehingga akan menggiring siswa berfikir secara deduktif yang berpengaruh terhadap rasa percaya diri siswa untuk dapat menguasai seluruh materi pembelajaran.

\section{KESIMPULAN DAN SARAN \\ A. Kesimpulan}

Berdasarkan analisis data hasil penelitian dan pembahasan, dapat disimpulkan sebagai berikut: Penerapan model pembelajaran remedial konsentris lebih efektif dibandingkan dengan pembelajaran konvensional untuk mengakselerasi hasil belajar siswa lambat mencapai kompetensi pada pembelajaran Kimia.

\section{B. Saran}

Berdasarkan kesimpulan tersebut, dapat disumbangkan saran untuk kemajuan pendidikan pada umumnya dan khususnya pembelajaran Kimia sebagai berikut:

1. Sebaiknya strategi pembelajaran Kimia dapat dilaksanakan menggunakan model pembelajaran yang beragam, antara lain menggunakan model pembelajaran remedial konsentris.

2. Diharapkan ada pihak terkait yang dapat melaksanakan penelitian lanjutan dengan populasi yang lebih besar sebagai pengembangan penelitian ini, sehingga diperoleh kesimpulan yang lebih tajam terhadap efektivitas model pembelajaran remedial konsentris untuk mengakselerasi hasil belajar siswa lambat mencapai kompetensi.

\section{DAFTAR PUSTAKA}

[1] Depdiknas. 2008. Perangkat Pembelajaran Kurikulum Tingkat Satuan Pendidikan (KTSP) SMA. Direktorat Manajemen Pendidikan Dasar dan Menengah Direktorat Pembinaan SMA Departemen Pendidikan Nasional, Jakarta.

[2] Badan Standar Nasional Pendidikan. 2009. Prosedur Operasi Standar (POS)Ujian Nasional (UN) Sekolah Menengah Atas/Madrasah Aliyah (SMA) MA) Tahun Pelajaran 2009/2010. Badan Standar Nasional Pendidikan, Jakarta.

[3] Nurasia. 2006. Penerapan Model Bermain Peran (Role Playing) untuk Meningkatkan Kemampuan Apresiasi Drama. Abstrak Tesis. Sumedang: SMP Negeri 1 Cimanggung, Sumedang. Jurnal Pendidikan, Volume 13, Nomor 1, April 2006. http://www.ind.sps.upi.edu/?cat=3, Diakses tgl 18 Desember 2008. 
[4] Caray, L. 2008. Prinsip-prinsip Dasar Pengajaran Remidial (Remidial-Teaching). http:// makalahdanskripsi.blogspot.com/2008/07/ prinsip-prinsip-dasar-pengajaran.html, Diakses tgl 28 Pebruari 2010.

[5] Chrisnajanti, W. 2002. Pengaruh Program Remedial Terhadap Ketuntasan Belajar Siswa. Jurnal Pendidikan Penabur. No.01 / Th.I/ Maret 2002.

[6] Sugiyono. 2009. Metode Penelitian Pendidikan (Pendekatan Kuantitatif, Kualitatif, Dan R\&D). Cetakan ke 7. CV. Bandung: Alfabeta.

[7] Sukmadinata, N.S. 2010. Metode Penelitian Pendidikan. Cetakan keenam. Bandung: PT. Remaja Rosdakarya.

[8] Irawan, P., et al. 2005. Metodologi Penelitian. Edisi Kesatu. Cetakan pertama. Jakarta: Universitas Terbuka.

[9] Mulyasa, H.E. 2009. Implementasi Kurikulum Tingkat Satuan Pendidikan. Kemandirian Guru dan Kepala Sekolah. Cetakan Ketiga. Jakarta: P.T. Bumi Aksara. 